\title{
Effect of Parent's Attention, Self- Concept, and Self- Study on Biology Students' Achievement at SMA Negeri 2 Sigi Biromaru
}

\author{
A. Tanra Tellu \\ Universitas Tadulako \\ Palu, Indonesia \\ tanratellu@untad.ac.id \\ Abdul Kadir \\ SMA Negeri 2 \\ Palu, Indonesia \\ abdulkadir@yahoo.co.id
}

\author{
Amiruddin Kasim \\ Universitas Tadulako \\ Palu, Indonesia \\ kasimamir@yahoo.co.id
}

\begin{abstract}
This study aims to explain the influence of parents' attention level, self-concept, and the self-study in SMA Negeri 2 Sigi Biromaru District Sigi student's achievement. The population in this study are all class XI students of the natural science department. The samples were selected through a saturated sampling technique (census). All variable data such as parents' attention level, self-concept, and self-study variable were collected using a questionnaire and report cards of achievement variables. The data obtained were analyzed through correlation and multiple regression analysis. Test instruments include the validity and reliability. Methods used in research are the validity of empirical formula of Pearson's moment product correlation and reliability using Cronbach Alpha coefficient formula.Obtained the parents' attention instruments is $\mathbf{0 . 8 8 3}$, self-concept instruments are $\mathbf{0 . 8 4 9}$, and self-study instrument is 0.928. The results showed that the tendency of student achievement in SMA Negeri 2 Sigi Biromaru District Sigi was very good in general. This research also obtained the influence of parents' attention $\mathbf{0 . 6 2 8}$, self-concept is $\mathbf{0 . 6 9 7}$, and self-study is 0.674. The effective contribution of parents' attention, selfconcept and self-study is $\mathbf{7 4 . 8 \%}$ to learning achievement. Based on these results it can be concluded that the parents' attention, self-concept, and self-study have a positive influence on student achievement.
\end{abstract}

Keywords-Parents attention, self-concept, self-study, students' achievement

\section{INTRODUCTION}

Student achievement is determined by many factors. These factors are generally divided into two groups, namely internal factors, and external factors. The internal factor is such as selfconcept and self-study, while external factor includes parental attention.

Parents' participation in the environment is very important to guide in order that children be able to do all duties and obligations of their own accord. These concerns will shape the personality of these children. If this had been formed in a child, it will make him easier in developing its potential.
The parents' attention in terms of children's education is required. Parents'attention to children's learning activities may include providing guidance and advice, observation of children's learning process, motivation and reward and fulfillment of children's learning needs. The attention plays an important role in determining the success of their children's learning.

Self-concept is an important aspect, especially in the learning process of students. The concept of a person is a frame of reference in interacting with the environment. Selfconcept is the perception, description and thorough assessment by a person against himself that are physical aspect, psychological, social and academic status or academic ability possessed.

Self-reliance is the tendency of children to do something you desire without assistance and can direct ways without being subject to any others. Self-reliance is an internal power obtained through the process of realization of selfhood and the process towards perfection. So self-reliance is someone's ability to think, feel, and do something to make a plan, choose alternatives, make decisions, resolve problems, and be responsible without the help of others.

The role of the three factors is playing an important role and strategic in achieving student achievement. though not only these three factors, but there are many other factors that are not addressed in this study.

Based on the initial survey results at SMAN 2 Sigi Biromaru, data showed that there are students who show less liable for his own good in the school environment, family environment, and family or in the community. In the school environment, for example, students arrived late in schools, even though leave from home since in the morning, do not attend classes during school hours, and any other example. Such conditions have an impact on student achievement.

The learning achievements reached some students at the school is still low. The latest data show the average value of 
National Examination (UN) on the biology subject in the academic year 2009 / 2010-2014-2015 was still very low. As an illustration, the average value obtained by the students in 2009 was 6.62 and in 2010 dropped to 3.87. It happened in the next five years until the year 2015/2016. The low score might have been caused by a lack of activity students in learning and lack of attention from parents on learning activities of students at home. The assumption of cause is based on the statement of some students who claimed that their parents rarely watched them learn at home. So it can be said that less at learning achievements reached by some students at SMAN 2 Sigi Biromaru highly correlated by lack of parental supervision on the activities of students, especially on studying at home, selfconcept and self-learning students.

\section{MethodS}

The experiment was conducted by using quantitative descriptive research, associative type. The relation of causality is cause and effect. The population in this study were 52 students of class XMIA SMAN 2 Natural Sciences Sigi Biromaru Academic Year 2010/2011. Samples were taken using nonprobability sampling technique. The sample collection is done with consideration the population is less than 100 , so the sample called saturated sample or sampling of the population.

The kind of data that take is the parent's attention, selfconcept, self-reliance and student achievement in biology. The data was undertaken a survey, documentation and interview technique. Data processing is done by a technique based on Likert scale, while data analysis was done by using multiple regression types of quantitative analysis, using SPSS data processing program.

\section{RESULTS AND DISCUSSION}

\section{A. Parents Attention}

Based on the results, in general, the parent's attention levels are 25 people or $48.08 \%$ classified as less concern, 16 people or $30.77 \%$ classified as category care and 11 people or $21.15 \%$ classified as category very attention to their children.

The average calculation of overall parent's attention quality done according to the formula: the sum of parent's attention score divided all respondents. So the average of parent's attention in students learning activities at SMAN 2 Sigi Biromaruis classified as category care since the score was between 93-112.

Based on the results of the regression analysis obtained a score of R Square is 0.628 or $62.8 \%$. This shows that the percentage contribution of parent's attention on learning achievement is $62.8 \%$, while the remaining $37.2 \%$ influenced by other variables in this study.

So, in this case, can be concluded that parent's attention contributes on student achievement, the more intense parent's attention is directly proportional to student achievement. These results are consistent with the claim that the intensity of parental guidance and attention can improve student learning outcomes [1]. The results of this study indicate that parent's attention in the implementation of education has some positive effects on student learning achievements and show the higher involvement and concern for the educational problems in school, increasing students learning achievements in the biology subjects. These findings support the claim that the parent's attention plays an important role in improving the results of research students learning [2].

\section{B. Self-Concept of Students}

Based on the results, in general, the self-concept levels are 19 people or $36.54 \%$ classified as less self-concept, 21 people or $40.38 \%$ classified as sufficient self-concept and 12 people or $23.08 \%$ classified as relatively high self-concept category.

The average calculation of overall students' self-concept done according to the formula: the sum of self-concept score divided all respondents. So the average of self-concept in students learning activities at SMAN 2 Sigi Biromaru is classified as category sufficient since the score was between 108-122.

Based on the results of the regression analysis obtained a score of R Square is 0.697 , or $69.7 \%$. This shows that the percentage contribution of self-concept on learning achievement is $69.7 \%$, while the remaining $30.3 \%$ influenced by other variables in this study.

So, in this case, can be concluded that self-concept contributes on student achievement, the more intense selfconcept is directly proportional to student achievement. Good self-concept can improve student learning outcomes, where the self-concept is an aspect of personality that can basically develop [3]. Lack of student self-concept may lead to academic problems and may also cause disturbances in the process of thinking and learning concentration. The value of individual self-concept is when it's lower or less, it will also follow by a low learning motivation. However, the achievement motivation is not only come from self-concept factors. There are other factors such as internal factors, external factors, and learning approaches.This finding is in line with the opinions stated that the self-concept of each student determines the success of the study.

\section{Independence Learning of Students}

Based on the results, in general, the learning independence levels are 21 people or $40.38 \%$ classified as less independent, 21 people or $40.38 \%$ classified as category quite independent and 10 people or $19.23 \%$ classified as the high independence of learning category.

The average calculation of overall students' learning independence done according to the formula: the sum of learning independence score divided all respondents. So the average of independent learning in students learning activities at SMAN 2 Sigi Biromaru is classified as sufficient since the score was between 103-117.

Based on the results of the regression analysis obtained a score of R Square is 0.674 or $67.4 \%$. This shows that the percentage contribution of learning independence on learning achievement is $67.4 \%$, while the remaining $32.6 \%$ influenced by other variables in this study.These results are consistent with the idea that the learning independence is important in improving activity and learning outcomes [5]. 
The results showed that the majority of these students is in category quite independence. Quite an independence is indicated by the average score or the sample mean is 105.86 . These results are in accordance with the opinion expressed that independent learning was different for each student [7].

\section{Learning Achievement of Students}

Based on the results, in general, the learning achievement levels are 16 people or $30.77 \%$ classified as good, 28 people or $53.85 \%$ classified as category quite well and 7 people or $15.38 \%$ classified as less well category.

The average calculation of overall students learning achievement is done according to the formula: the sum of students learning achievement score divided all respondents. So the average of learning achievement in students learning activities at SMAN 2 Sigi Biromaru is classified as quite good since the score was between 68-75. These results are in line with the opinions stated that student achievement varies, depending on the situation and the psychological condition of the students[4].

\section{E. Effect of Parents Attention on the Self-Concept Students}

Based on the results of the regression analysis obtained a score of R Square is 0.657 or $65.7 \%$. This shows that the percentage contribution of parent's attention against selfconcept is $65.7 \%$, while the remaining $34.3 \%$ influenced by other variables in this study.So we can conclude that parent's attention against self-concept, the more intense parent's attention is directly proportional to high self-esteem for students can learn, do school projects and develop themselves to be successful on their own.

One option can be selected by parents is to provide protection, confidence, and guidance to children so as to have a high self-concept. From this research, it can be concluded that most of the time children are in a family environment so that the welfare of children in child physical and spiritual needs fulfilled, harmonious communication, parent's attention and trust among parents and child, will form the true selfconcept for children. These conditions are in line with the development and activity of students [4] [9].

\section{F. Parents Attention Influence of the Student Learning Independence}

Based on the results of the regression analysis obtained a score of R Square is 0.738 or $73.8 \%$. This shows that the percentage contribution of parent's attention against learning independence is $73.8 \%$, while the remaining $26.2 \%$ influenced by other variables in this study. So we can conclude that parent's attention against learning independence, the more intense parent's attention is directly proportional to students learning independence.

Balance is parent's attention to its duties who thoroughly so that each duty demanding attention in accordance with the busway management.For example, parents focus on their children's learning attention, guidance and motivation in learning and providing learning facilities that are needed so that children develop to have a high learning independence and capable of getting an achievement and success of his efforts [1]. Also in accordance with the opinion of Chang, et al.(2010) which states that the attention of parents is important in establishing the independence of learners[8].

\section{G. Effect of Self-concept of the Student Learning Independence}

Based on the results of the regression analysis obtained a score of $\mathrm{R}$ Square is 0.741 or $74.1 \%$. This shows that the percentage contribution of self-concept against learning independence is $74.1 \%$, while the remaining $25.9 \%$ influenced by other variables in this study. So we can conclude that selfconcept against learning independence, the more intense parent's attention is directly proportional to students learning independence.

Based on the research that positive self-concept on students, learning the dynamic and participatory learning independence are methods and techniques that are very appropriate to be applied in schools.Students can directly involve in the learning process since the beginning of the planning, implementation, and evaluation of learning strategies. The results of the study in accordance with hypothesis advanced by researchers, That is there is a positive influence between self-concept against the independence of learning, so the higher self-concept, then the higher would be the students' independent learning. These results are consistent with the idea that the self-concept affects the independence of learners [10].

\section{H. Effect of Parents Attention, Self-Concept, and Independence Learning toward Student Achievement}

Based on the results of the regression analysis obtained a score of $\mathrm{R}$ Square is 0.748 or $74.8 \%$. This shows that the percentage contribution of parents' attention, self-concept and learning independence on student achievement is $74.8 \%$, while the remaining $25.2 \%$ influenced by other variables in this study.

The analysis showed that the level of parents' attention, self-concept and learning independence on student achievement in SMAN 2 Biromaru Sigi district of Sigi is in category sufficient. The picture shows that not all parents understand the importance of parents' attention on improving learning achievement of student in school. If it is ignored by the parents, it can affect student learning outcomes [11]. Hence, understanding the importance of parents' attention should be emphasized on parents [12]. Based on its need to pay serious attention from the school, from the government, society and in particular from the parents themselves. Results of other studies indicate that parental attention, self-concept, and self-learning is an important component in improving student learning outcomes and these three cannot be separated from each other [13] [14] [15].

\section{CONCLUSION}

Parents attention, self-concept and learning independence of student learning effect on the learning achievements, either as the single factor or simultaneously. Parents attention has an impact on self-concept and students learning independence of SMAN 2 Sigi Biromaru. Self-concept affects the independent learning of students at SMAN 2 Sigi Biromaru. 


\section{ACKNOWLEDGMENT}

Further, thanks to the principal of SMAN 2 Sigi Biromaru along with teachers and staff by the permission and by the leave of assistance provided for this study was conducted.

\section{REFERENCES}

[1] Adnan; Faisal; dan Marliyah. Studi Motivasi Siswa SMP dan Sederajat di Kota Makassar pada Mata Pelajaran IPA Biologi. Jurnal Bionature. Vol. 13, No. 2, pp. 103-107. 2012.

[2] Arend, R.I. Learning to Teach. Nine edition. Mc Graw Hill. Connect Learn Succeed. 2012.

[3] Artino, A.R. Philosophy, and Pedagogy Statement: Cognitive Constructivism and the Influence of Motivation and Context. The University of Connecticut. 2011

[4] Asrori, M. Psikologi Pembelajaran. Bandung: Wacana Prima. 2007.

[5] Bas, G. Investigating the Correlation Between Students' Perceptions of the Constructivist Learning Environment and their Academic Success in Science Course with Path Analysis. Journal of Baltic Science Education (online), Vol. 11, No. 4, pp. 367-379. 2012.

[6] Bele, J. L; Debevc, M; Morel, I and Rozman, D. Creating a Positive Attitude Towards E-Learning at Work Post. iJAC, (online), Vol. 1, No. 1, pp. 17-21. 2008.

[7] Benson, V, and Anderson, D. O \& Ooms, A. Educators' Perceptions, Attitudes and Practices: Blended Learning in Business and Management Education. Research in Learning Technology, (online), Vol. 19, No. 2, pp. 143-154. 2011.
[8] Chang, C.Y., Peng, H. Y., dan Chao, C. H. Examining the Effects of Learning Motivation and of Course Design in an Instructional Simulation Game. Interactive Learning Environments (online), Vol. 18, No. 4, pp. 319-339. 2010.

[9] Kang, H; Scharmann, L.C; Kang, S; \& Noh, T. Cognitive Conflict and Situational Interest as Factors Influencing Conceptual Change, International Journal of Environmental \& Science Education, Vol. 5, No. 4, pp. 383-405. 2010.

[10] Sevinc, B; Ozmen, H; \& Yigit, N. Investigation of Primary Students' Motivation Levels toward Science Learning. Science Education International, Vol. 22, No. 3, pp. 218-232. 2011.

[11] Bu, H. \& Bu, S. Study on Innovation Teacher Training in Basic Education from The Perspective of "Blended Learning". International Education Study. 2012.

[12] Gaeta, L. M; Teruel, P. M; \& Orejudo, S. Motivational, Volitional and Metacognitive Aspects of Self Regulated Learning. Electronic Journal of Research Psychology, Vol. 10, No. 1, pp. 073-094. 2012.

[13] Keller, J. M. \& Suzuki, K. Learner Motivation and E-Learning Design: A Multinational Validated Process. Journal of Educational Media, Vol. 29, No. 3, pp. 229-239. 2004.

[14] Gredler, M. E. Learning, and Instruction: Theory into Practice. Interpret by: Wibowo, T. 2011. Jakarta. Penerbit Kencana Prenada Media Group. 2011.

[15] Margueratt, D. Improving Learner Motivation through Enhanced Instructional Design. Thesis Master of Distance Education. Athabasca University. 2007. 